\title{
Helpdesk System At PT Himalaya Everest Jaya Jakarta
}

\author{
Embun Fajar Wati \\ Universitas Bina Sarana Informatika \\ Jakarta, Indonesia \\ e-mail: embun.efw@bsi.ac.id
}

\author{
Dedi Maryadi \\ Stikom Cipta Karya Informatika \\ Jakarta, Indonesia \\ e-mail: dedidenz21st@gmail.com
}

\begin{abstract}
PT Himalaya Everest Jaya, a company engaged in importers, exporters of electricity and mechanics. In its daily life, PT Himalaya Everest Jaya has used information technology in its operational activities. But problems are often found in supporting operational activities in the field. Where this can hamper the work of every employee who uses it. The problems that often occur include hardware, software, and network connections. Current problem submission is still not effective because employees who have problems must contact the IT directly or by using the telephone. Likewise with recording problems, because the EDP / IT still records every problem using a paper that can be lost or damaged at any time. Therefore, an integrated Helpdesk application is needed and can be accessed quickly by employees and the EDP / IT division. The method used in designing this application is based on the Web, to find out which system is running, the author uses several tools such as Flowmap and UML (Unified Modeling Language), while the system development method uses the Waterfall method. The supporting software used is Xampp, and MySQL as the builder and program documentation. With the existence of a web-based system that has been connected to this database, the process of delivering and handling complaints is expected to be resolved properly and quickly in its handling.
\end{abstract}

\section{Keywords- Helpdesk, UML, Complaint, Application, EDP}

\section{INTRODUCTION}

In companies, each division plays a role in the process of running a company, especially in the EDP (Electronic Data Processing) division. EDP is part of IT, the EDP Division plays an important role, especially in the Information and Communication Technology (ICT) section. Every network, computer, hardware, and software device are the responsibility of the EDP division. Every problem related to ICT will be handled by EDP. But unfortunately, many companies limit the number of workers from the EDP division. As a result they are required to work harder in solving each problem.

At present there are many large companies that apply the application report to find out the company's performance. The report is very useful for the company by reporting what problems arise. With this report the company will know what problems are being faced by the company. A report that can also help management to see the development of the company.

However, currently there are no applications that have been used by PT. Himalaya Everest Jaya to provide systematic reports. All recordings of reports, monthly reports, replacement of units, and calculation of problems related to EDP are still done manually. This can have a negative impact, including: there is a risky problem recorded repeatedly, problems that are forgotten are recorded because of the busy operators in receiving calls, work that is left behind and forgotten, solving unordered problems, employees or users who do not understand problems on the computer will experience confusion in reporting the problem to anyone because of the many different divisions in each problem handling and also a lack of user knowledge of computer problems.

Based on the above problems, it needs a wellintegrated Helpdesk application so that accessing data on the Helpdesk can be done easily and quickly to search and measure problem levels and access reports by the head of the IT division. Problems can be handled properly and produce the right solution. In addition, to facilitate access by those who need it, this application will be built on a web-based basis. Helpdesk applications are important to use for companies because basically the helpdesk is a 
complementary part of a service function and is responsible as a source of service and as a source of other problem solving. [1]

\section{RESEARCH PREVIOUS}

- [3] A journal entitled "PENGEMBANGAN MODEL SISTEM INFORMASI APLIKASI HELPDESK ONLINE PT. MUSTIKA MEMADATA". This study discusses the design of online helpdesk application modeling aimed at dealing with the problem of monitoring customer complaints by PT. Mustika Memadata. The results to be achieved are designing an appropriate helpdesk application to overcome the company's problems.

- [4] A journal entitled "SISTEM INFORMASI IT-HELPDESK PADA UNIVERSITAS AMIKOM YOGYAKARTA BERBASIS WEB". This study discusses how to build information systems for users, consumers and management of IT Helpdesk. The IT Helpdesk provides several forms of services that can be utilized by the academic community at AMIKOM Yogyakarta University in using ICT services. Services of this unit include installation, software troubleshooting, service and computer maintenance.

- [5] A journal entitled "Perancangan Sistem Informasi Helpdesk Menggunakan Framework ITIL V3." The purpose of this study is to analyze the appropriate ITSM framework in the development of the Helpdesk, Information System at PT Len Industri (Persero) which is one of the organizations of State-Owned Enterprises (BUMN). Helpdesk services provided include repairs to hardware, software, and networks.

\section{LITERATURE REVIEW}

\section{A. Helpdesk System}

The Helpdesk is a Single Point Of Contact (SPOC) which is a communication facility between customers or users and a support team in a product or service provider company. To facilitate the company in handling complaints and questions from customers. [2]

\section{PROPOSED METHOD}

The research method used is :

- Method of collecting data
1) Library study: references used in this study include, among others, journals and books related to the helpdesk system.

2) Observation: direct observation of the help desk process that is running, studying the shortcomings that exist and making temporary conclusions of the problems that occur in order to facilitate the process of data collection.

3) Interview: Question and answer is conducted in a structured manner by giving several questions directly to the head of the IT department.

- The analytical method used is a qualitative method.

- The processing/design method used is by the waterfall method, which is the execution of a system carried out sequentially or linearly. Design depiction using UML (Unified Modeling Language) diagrams.

\section{RESULTS AND DISCUSSION}

A. Analysis of The Running System

The diagram used to analyze the running system can be seen in the figure 1 flowmap diagram of the system running.

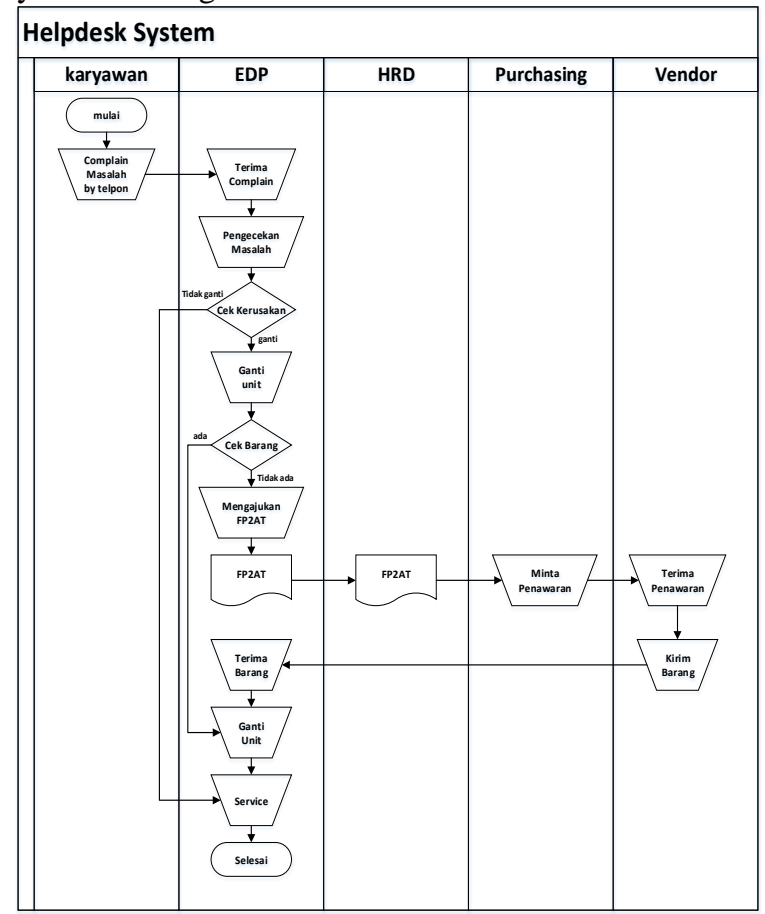

figure 1. Flowmap of The Running System 
B. Design of The Proposed System

The diagram used to design the proposed system is a flowmap diagram, UML diagram (Use Case, Sequence, and Class Diagram), chart of the applications structure and interface design.

- Flowmap of The Proposed System

Flowmap diagram of the proposed system can be seen in figure 2 and figure 3 below.

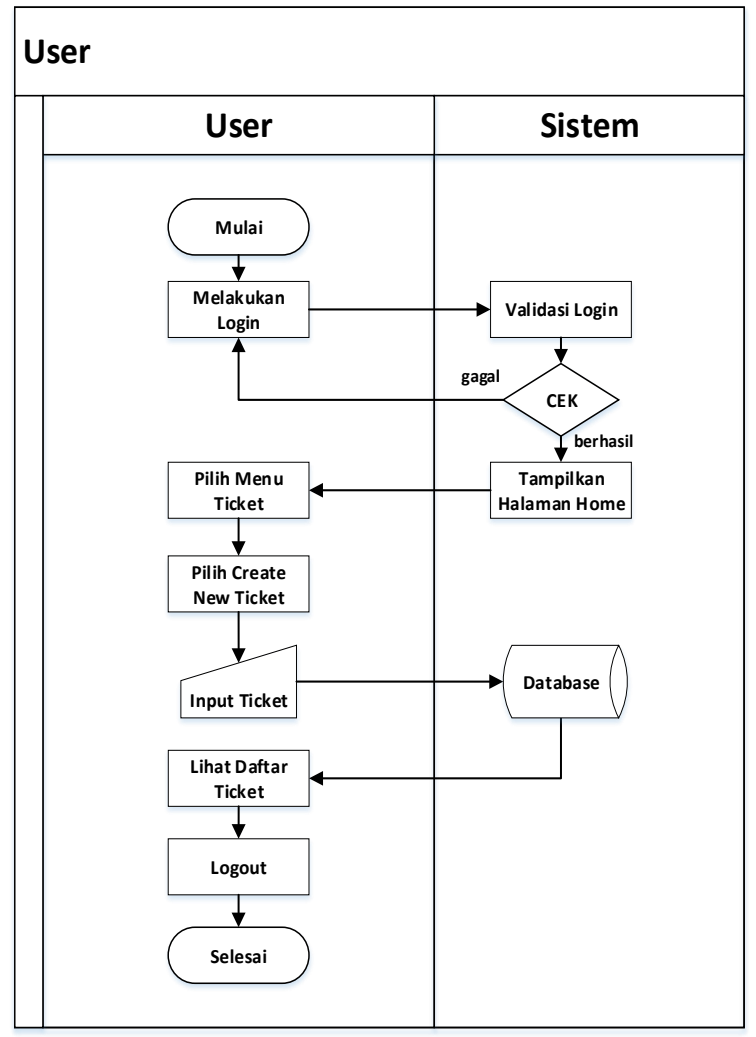

Figure 2. Flowmap of The Proposed System for User

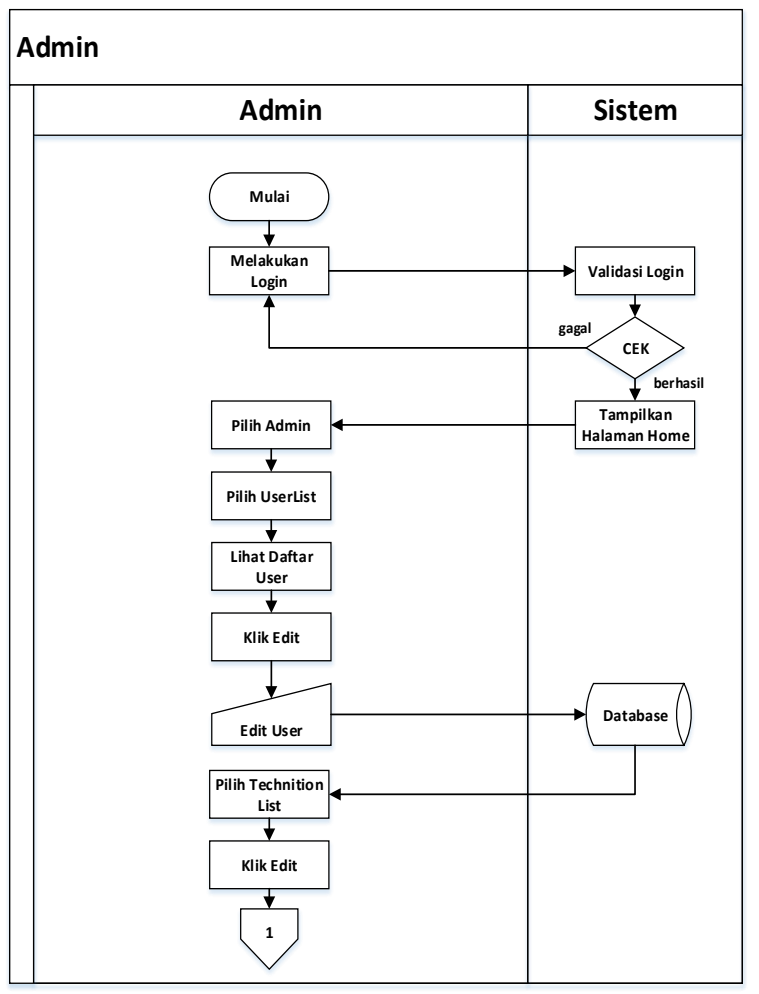



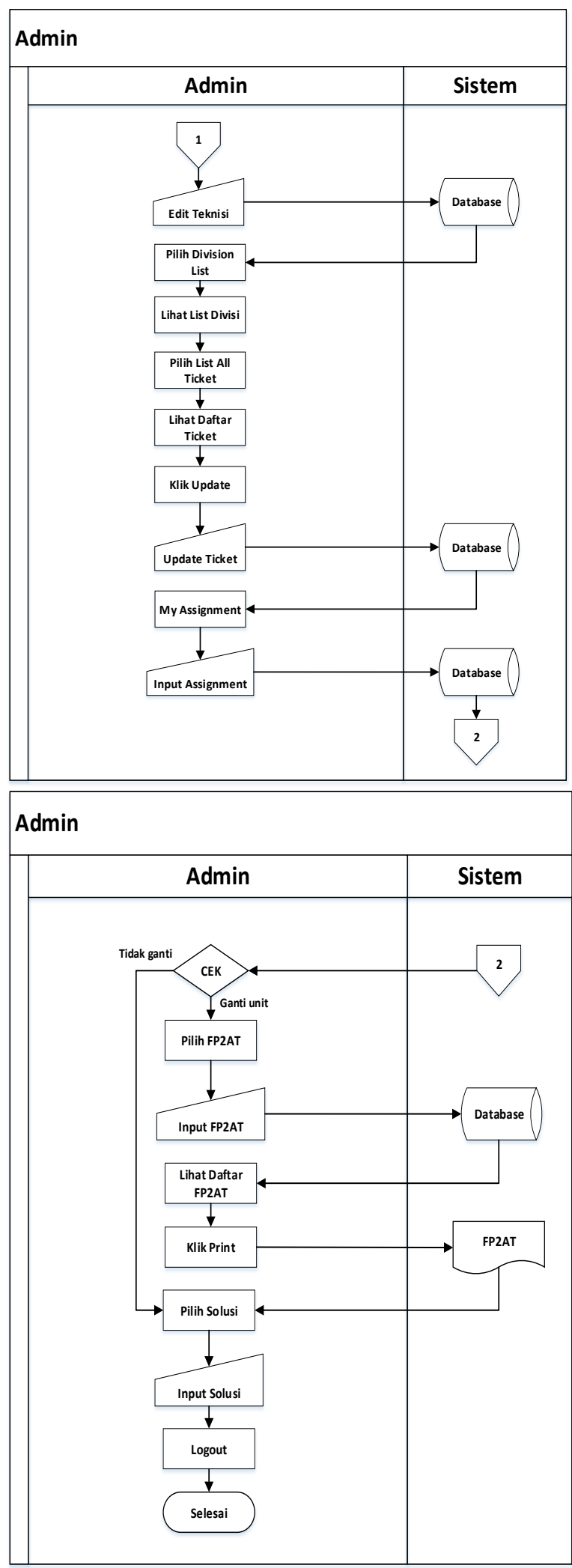

Figure 2. Flowmap of The Proposed System for Admin

\section{- Use Case Diagram}

Figures 4 and 5 show Use Case Diagram of The Proposed System.

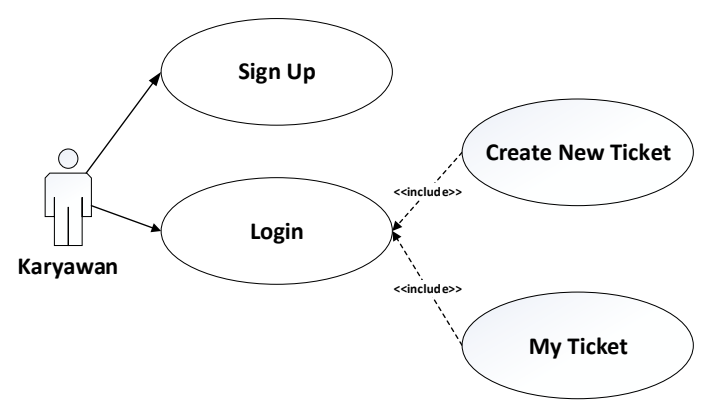

Figure 4. Use Case Diagram for User

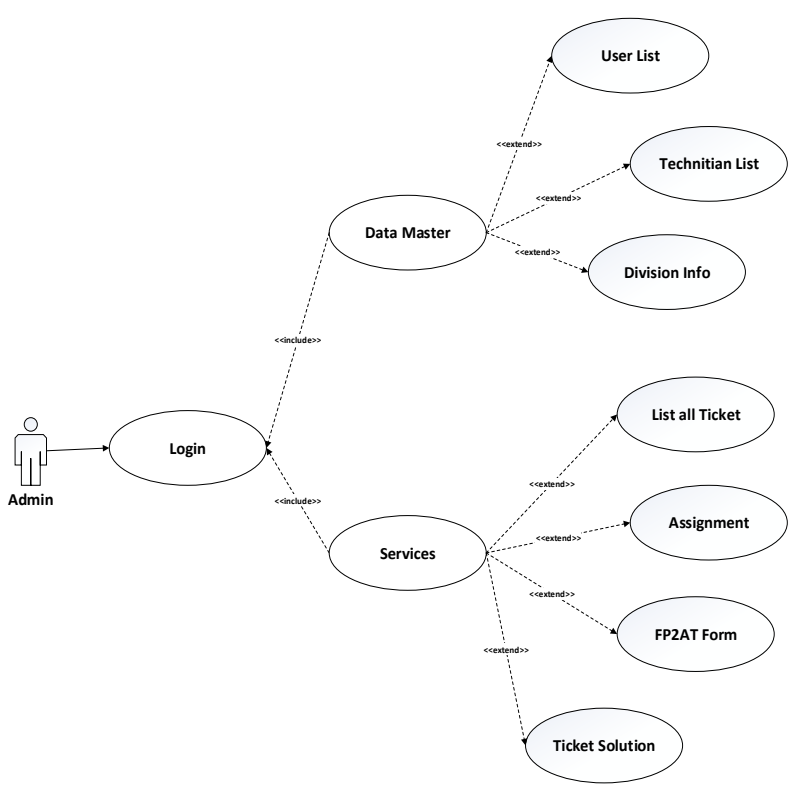

Figure 5. Use Case Diagram for Admin

- Sequence Diagram

Sequence diagram can be shown in figures 6 and 7. 


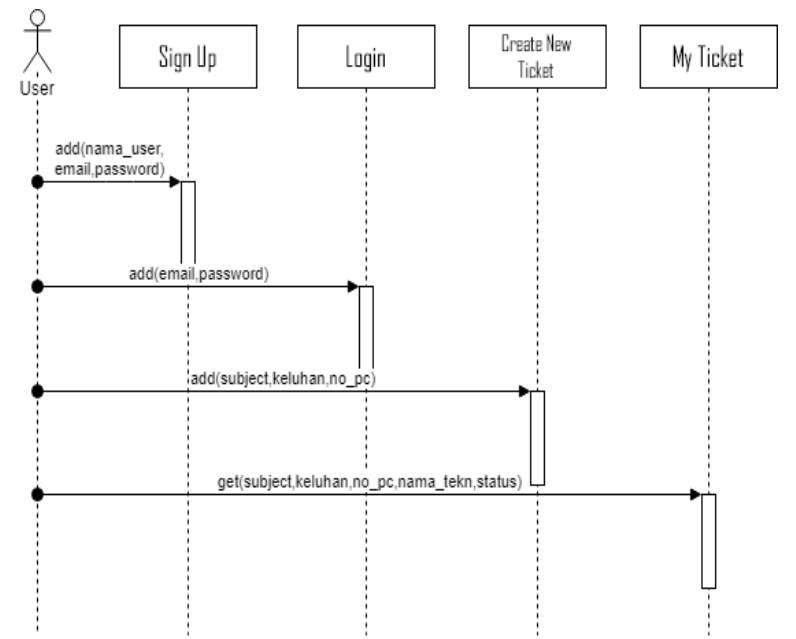

Figure 6. Sequence Diagram for User

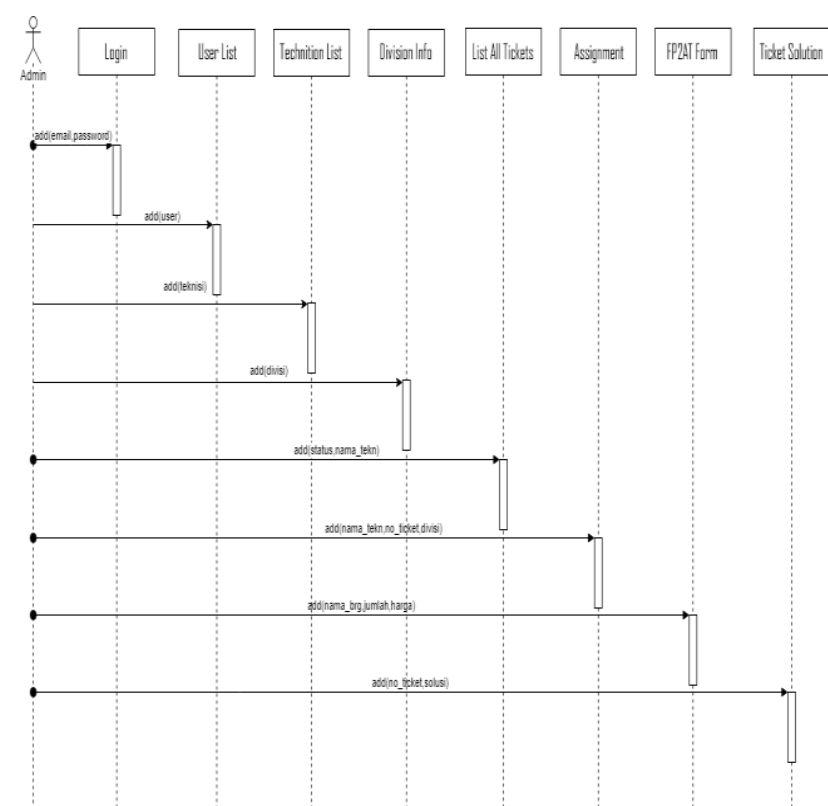

Figure 7. Sequence Diagram for Admin

- Class Diagram

Class Diagram on the proposed system can be seen in figure 8.

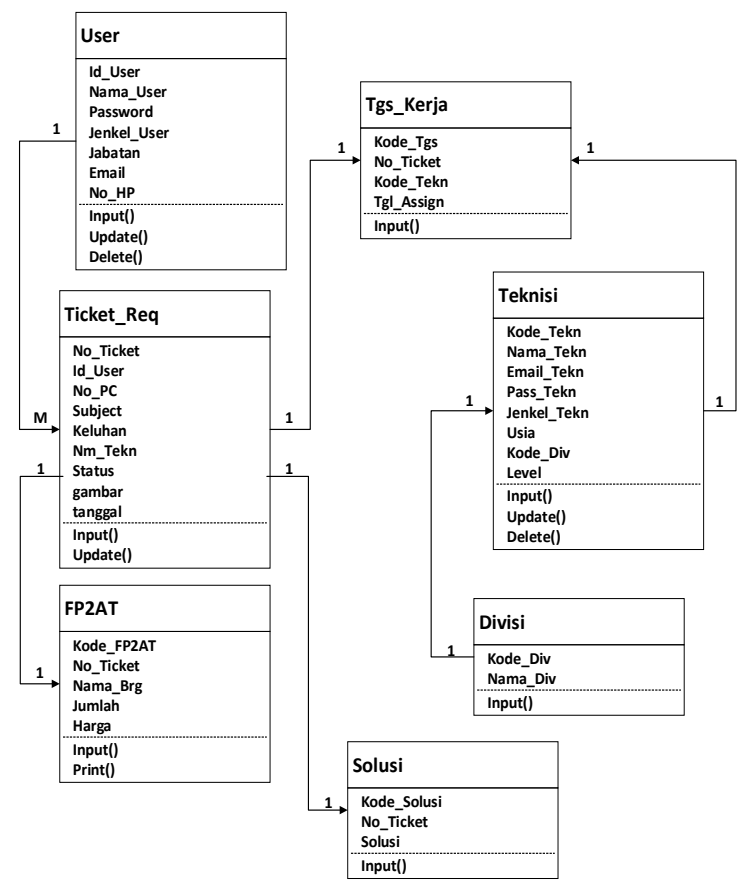

Figure 8. Class Diagram

- Chart of Application Structure

Figure 9 shows the chart of application structure

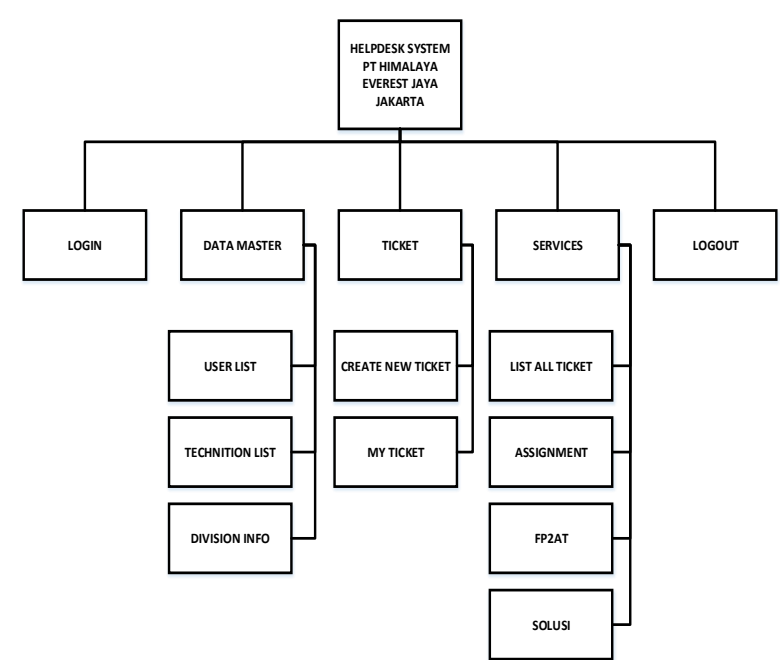

Figure 9. Chart of Application Structure

- Design of Interface

The interface is the final result of the proposed system design which can be seen in the pictures below. 


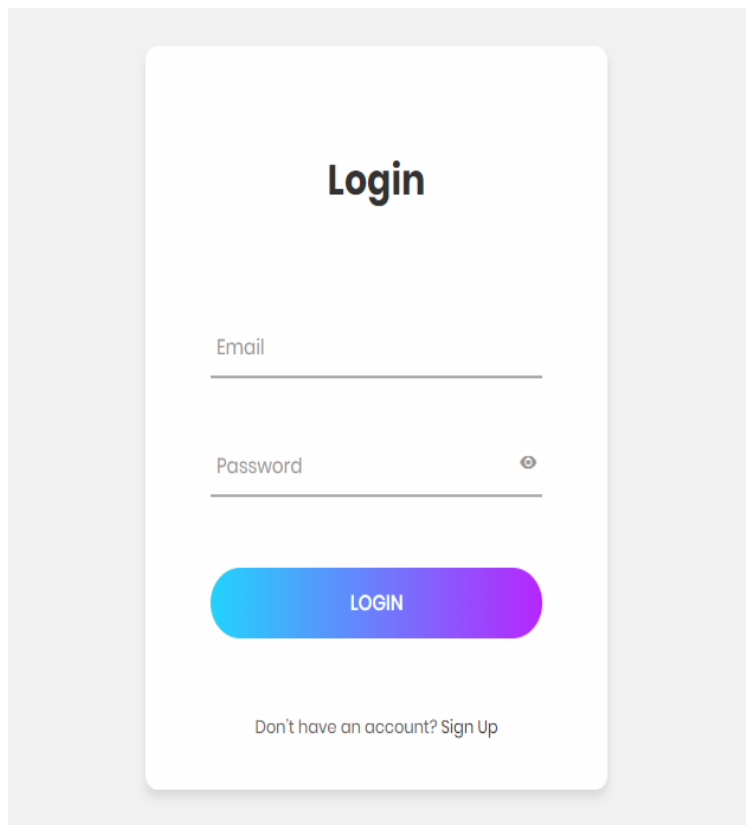

Figure 10. Login Interface

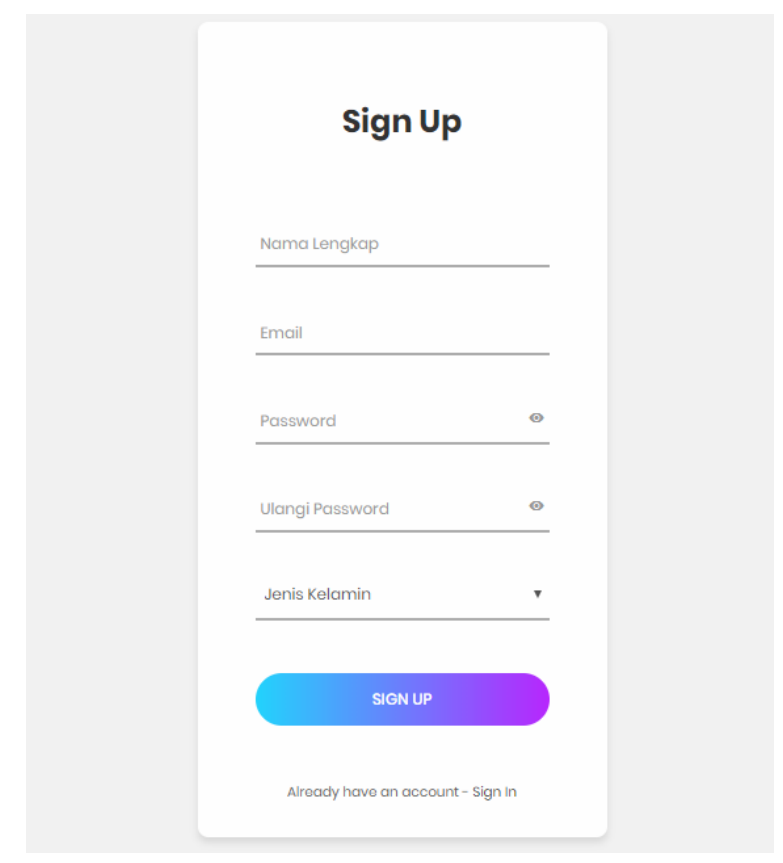

Figure 11. Sign Up Interface

$$
\text { Antentisten }
$$

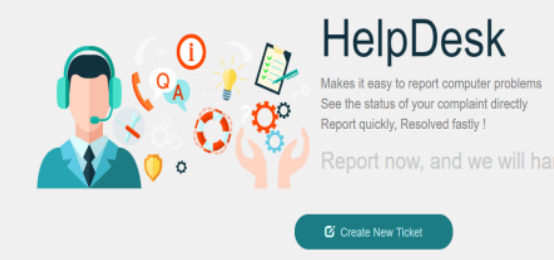

Figure 12. User Home Interface

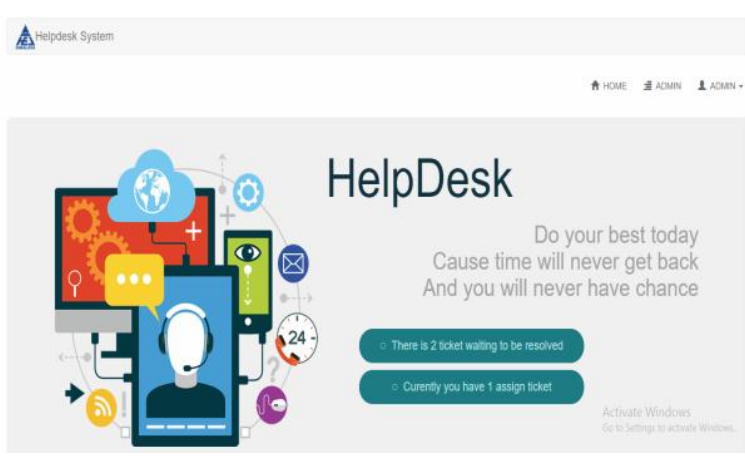

Figure 13. Admin Home Interface

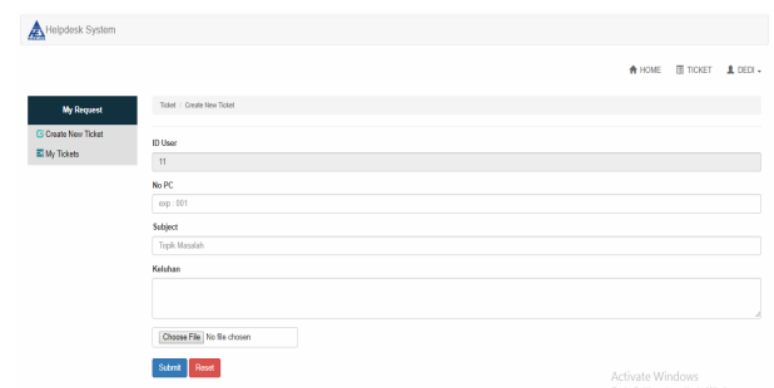

Figure 14. New Ticket Interface

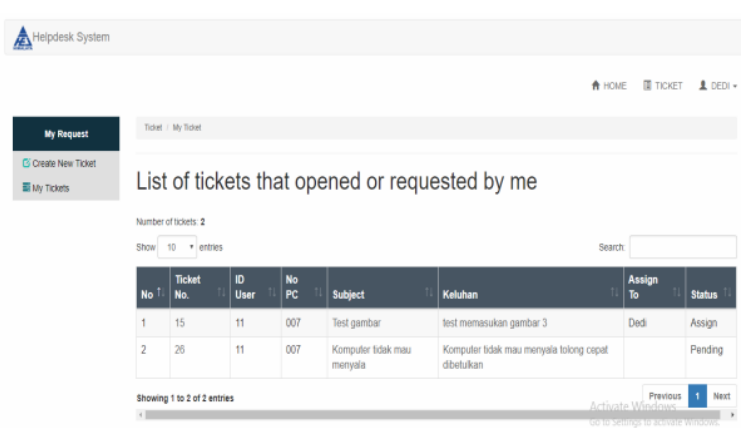

Figure 15. My Ticket Interface 


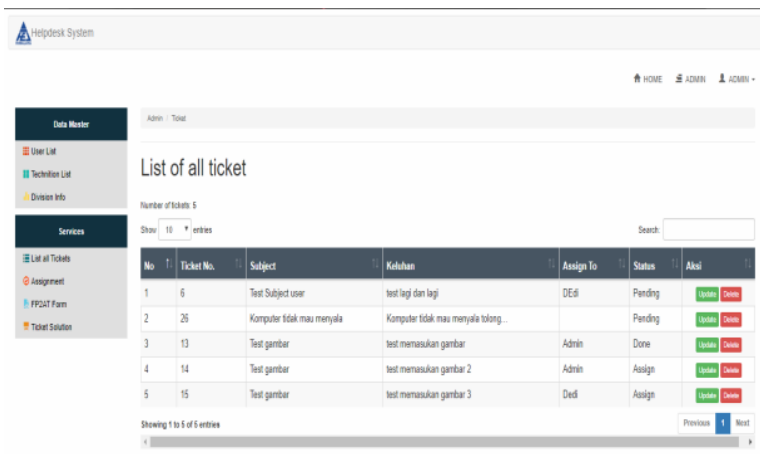

Figure 16. Ticket List Interface

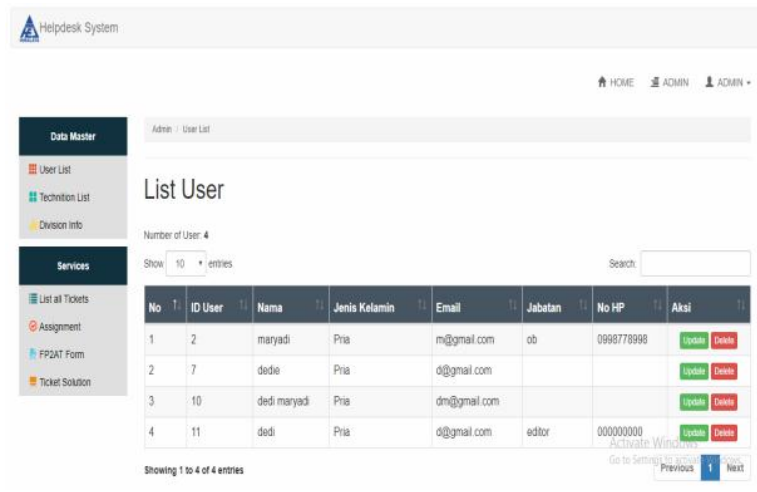

Figure 17. List of User Interface

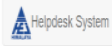

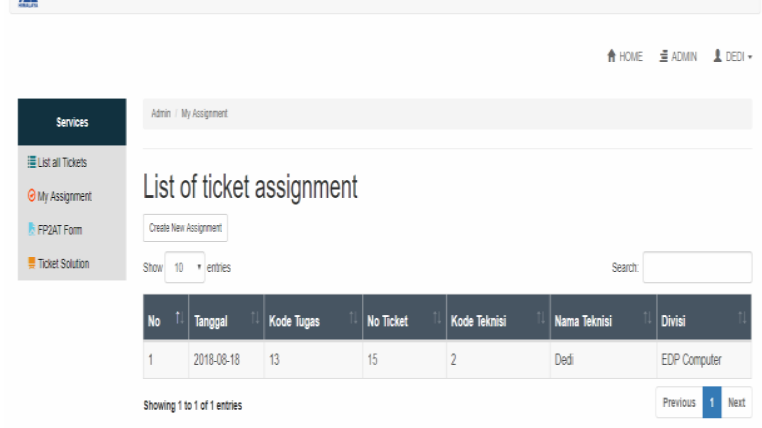

Figure 18. My Assignment Interface

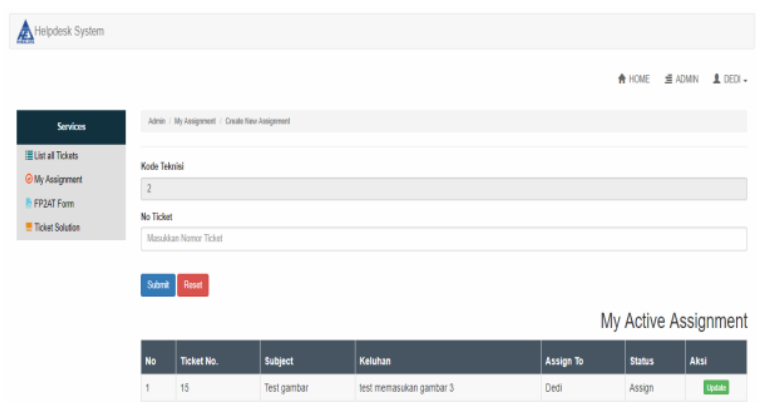

Figure 19. New Assignment Interface

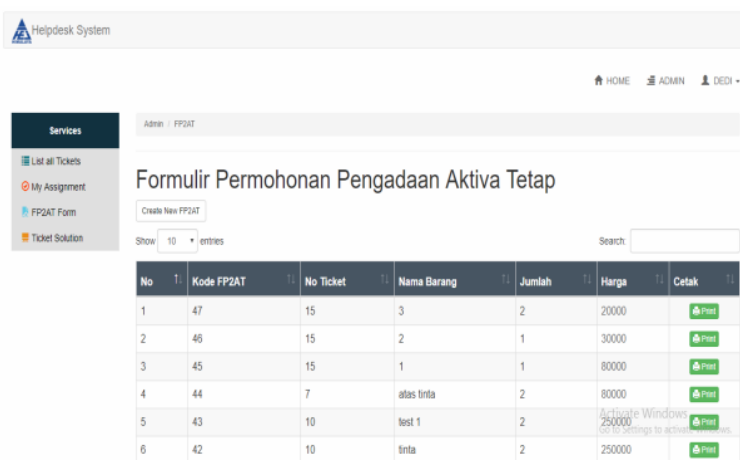

Figure 20. FP2AT Interface

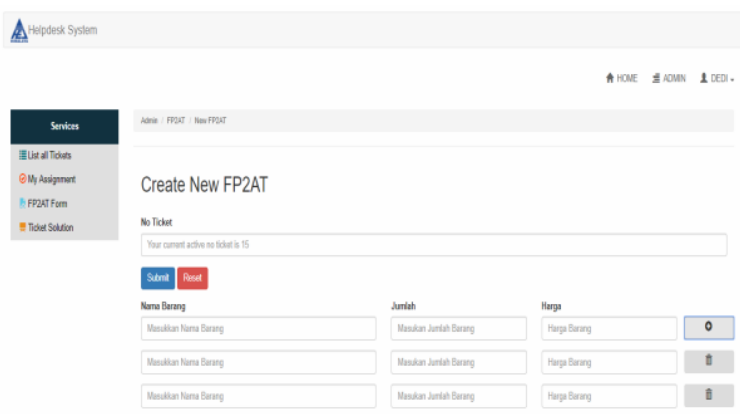

Figure 21. New FP2AT Interface

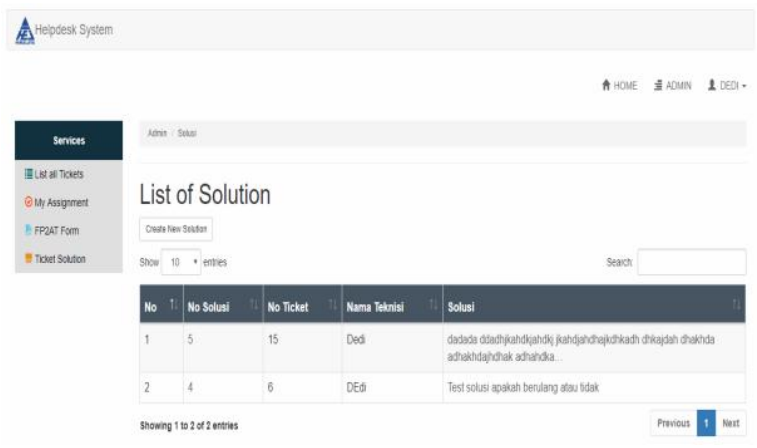

Figure 22. Solution Interface

\section{CONCLUSIONS AND SUGGESTIONS}

Based on the research that has been done, some conclusions can be taken as follows:

- This application makes it easy for employees or users to report problems related to their computer devices and also see the status of these problems.

- All records are carried out in one application which can be accessed by each user according to their role in the ticket flow.

- Searching for solutions to damage is easier because each problem records in one application that can be accessed by all EDP division members. 
Based on the results of research and analysis carried out at PT Himalaya Everest Jaya, suggestions for development are needed, namely:

- This application system can be further developed, such as adding details of changing ticketing status, email connection.

- This application is not only used in web browsers, but can be used on mobile devices.

- Backup data to anticipate data loss/damage.

- Good cooperation between system users, so that the desired results and objectives in this application can be achieved.

\section{REFERENCES}

[1] R. I. Manopo, H. Wowor, and A. Lumenta, "Perancangan Aplikasi Help Desk Di UPT-TIK Unsrat," E-Journal Tek. Inform., vol. 8, pp. 57-63, 2016.

[2] H. Santoso, Membuat Helpdesk System Berbasis OOP \& PDO Dengan PHP. Yogyakarta: Lokomedia, 2014

[3] C. Cassandra, "Pengembangan Model Sistem Informasi Aplikasi Helpdesk Online PT. Mustika Memadata," COMTECH, vol. 6, pp. 173-184, 2015.

[4] A. Mustopa, "Sistem Informasi IT-Helpdesk Pada Universitas AMIKOM Yogyakarta Berbasis Web," JIKO, vol. 2, pp. 92102, 2017.

[5] E. M. Sipayung, C. Fiarni, and E. Aditya, "Perancangan Sistem Informasi Helpdesk Menggunakan Framework ITIL V3," JNTETI, pp. 141-151, 2017. 